\title{
Malaysian Youth Perception Towards Let's Get Vaccinated Campaign Conducted by the Malaysian Government on Social Media
}

\author{
Mohammad Nurhafiz Hassim*, Nur Nasliza Arina Mohamad Nasir, Norena Abdul \\ Karim Zamri, Syaza Marina Ramli
}

UiTM Alor Gajah Campus, Melaka, Malaysia

${ }^{*}$ Corresponding author. Email: hafiszhassim@uitm.edu.my

\begin{abstract}
The goal of the Let's Get Vaccinated Campaign in social media is to provide public awareness and exposure on the importance of taking the vaccine to prevent the spread of Covid-19. For example, a campaign like 'Yakinivaksin' is an awareness campaign aimed at fighting myths and misunderstandings about the COVID-19 vaccine. The objective of this study is to investigate Malaysian Youth perception towards The Let's Get Vaccinated Campaign conducted by the Malaysian Government on social media. This study applied a qualitative method of focus group discussion in order to collect the data from the targeted informants, which were Malaysian Youths. The results show that, although Malaysian Youths have a positive perception towards the Let's Get Vaccinated Campaign conducted by the Malaysian Government on social media, the campaign does not affect the beliefs and behaviour of Malaysian Youths regarding the importance of vaccination.
\end{abstract}

Keywords: Let's Get Vaccinated Campaign, Malaysian Government, Perception, Malaysian Youths, Social Media

\section{INTRODUCTION}

The National COVID-19 Immunization Program, which began on February 24, 2021, showed positive results, especially for Malaysia, as the number of positive cases of COVID-19 declined than before the vaccines [1]. This proves the efforts of the government to foster Malaysians taking the vaccine have been successful. We can see as an example of the campaigns conducted by the government to promote awareness of the community that vaccines are safe for all groups. Among the Let's Get Vaccinated campaigns that have been conducted are 'Lindungi Diri Lindungi Semua' and 'Jom Vaksin'.

The government also uses social media in a national vaccination campaign, such as on YouTube, Facebook, Instagram, and others. Among the social media campaigns are 'Elakkan 3C, Amalkan 3W' on YouTube, getting views of 82,000 people by the Ministry of Health Malaysia (MOH). In addition, on Facebook, MOH also launched the 'Daftar Vaksin Sekarang' campaign and the 'Kapsul KKM' published by the $\mathrm{MOH}$ Corporate Communications Unit to provide COVID-19 information to Malaysians [2]. Using social media in a new campaign facilitates social interaction and word of mouth online. It can expand the reach and accelerate the dissemination of information about something new [3]

Statistics released by the Malaysian Communication and Multimedia Commission (MCMC) [4] showing $86.5 \%$ of Internet users share online content via social media, by 2020 , compared to 2018 , which only recorded a percentage of $73.8 \%$. It shows that social media is a powerful tool for the public, and their story-sharing movement reaches new audiences worldwide [5]. Hence effective campaigns prevent the youth from being influenced by the harmful elements that are trying to convey the anti-vaccine, as we know these youths are easily influenced [6] and with an effective campaign can change the behaviour and attitude of a person for the better [7]. According to [7], the youths are state assets and future leaders. Youth are indispensable by the community and the country as these groups are a catalyst for national development. 


\section{LITERATURE REVIEW}

This subtopic will discuss the issue related to the Let's Get Vaccinated Campaign conducted by the Malaysian Government. The subtopic includes the previous study of the Let's Get Vaccinated Campaign by the Malaysian Government, Malaysian Youth, social media in Malaysia, and vaccine hesitation.

\subsection{Let's Get Vaccinated Campaign Conducted by Malaysian Government}

The National Vaccination Campaign conducted from 24 February 2021 involved all government sectors, especially the Ministry of Health Malaysia (MOH), which promoted vaccination campaigns to the public every day. Among the campaigns undertaken by the government are 'Lindungi Diri Lindungi Semua', and 'Jom Vaksin' following COVID-19 cases in Malaysia which have reached 20,000 a day around August 2021. Looking at this situation, the government has been working with opening a vaccine centre (PPV) first at Putra World Trade Centre Kuala Lumpur (PWTCKL) on 5 May 2021 [8] and subsequently opened in all states in Malaysia.

The campaign was held to provide awareness to the public to get the COVID-19 vaccine and later not be deceived by the Anti-Vaccine [9], with the consumption of approved COVID-19 vaccines in Malaysia such as Pfizer, Astra Zeneca, Sinovac, Sinopharm, and Johnson \& Johnson, to control the spread of Covid-19 disease. When more people get vaccinated, more people form antibodies and thus reduce the probability of worse Covid-19 disease. Indirectly, it can protect those who are at risk of being infected [10].

According to [11], media and communication were an effective medium to deliver information to the public-on-public health issues, nurture and provide awareness of the community on various effects of public health problems, and also educate as well as change the mind, perception, attitude, and behaviour of society. Past studies such as the 'Tak Nak Merokok' campaign organized by the government have succeeded in positively affecting hardcore smokers when some try to quit smoking after seeing the graphics found in the cigarette box. They highlighted a variety of pictures, such as mouth cancer, heart disease, etc. [12].

In addition, campaigns run on the Internet, and social media make it easier for people to get reliable information through official platforms such as Facebook and Twitter [13]. Measurement of the effectiveness of a campaign is through the role of public relations to ensure that local and international communities are constantly gaining information regarding current issues [14] and communication strategies conducted either on television, radio, newspaper, or Internet use [15]. Therefore, this study will explore the Malaysian Youth's perception of the Let's Get Vaccinated Campaign conducted by the Malaysian Government on social media.

\subsection{Malaysian Youth}

Youth has not been agreed globally in defining their age group. However so, the United Nations (UN) defined 'youth' - for statistical purpose - as any individuals between the age group of 15 and 24 years which was once discussed during the International Youth Year (1985) and endorsed by the General Assembly which resolved in the resolution $36 / 28$ of 1981 [16]. As of today, UN stated that there are about 1.2 billion young individuals aged 15 to 24 years which is equate to $16 \%$ of the world population and it was targeted for Sustainable Development Goals (SDG) that by 2030 , youth should have grown up to $7 \%$ which is up to nearly 1.3 billion.

In the Malaysian context, youth was originally defined as individuals aged between 15 and 40 [17]. Amendment was made to the Youth Societies and Youth Development Act (Amendment) 2019 (Act 668) in reducing the generation gap by the then Youth and Sports Minister, Syed Saddiq Syed Abdul Rahman. The amendment in youth groups was made in order to accelerate the maturity of youth, reduce the generation gap as well as risk behaviour. Hence, the amendment declared that youth in Malaysia is now included those in the age group of 15 to 30 years.

The differences in identity for youth as siblings, child, peer, friend, teen, and many more have affected the way one builds their understanding towards youth especially in research [18]. The Central Asian approach in defining the youth as individuals aged older than 13 and younger than 31 [19]. This group of people in the age group was considered as a youth in Central Asia due to the cohesive transition for their position based on their status legally, professionally, and academically while at the same time it corresponds to the presented concepts of national youth policy in Central Asian.

Youth was not only characterised based on their physical state but also based on their maturity in terms of socio-psychological state [20]. At the same time, it was also defined as a timely transition from the time of being kids towards adulting. Such time was the time in which these individuals will experience changes in many aspects mainly cognitive, emotional, social as well as moral [21]. The development and growth of youth will always relate to the state of reaching puberty which brought the growth to several levels mainly early 
adolescence (11 to 13 years old), middle adolescence (14 to 17 years old), and late adolescence (18 to 20 years old). The characteristics of each group will be defined as follows [22]:

\section{Early Adolescence (11 to 13 years old)}

Individuals in the early adolescence group felt closer to their peers, more egocentric and filled with feelings of wanting to be free. The egocentric character is when one chooses to look at things from their own perspective without considering the opinions of those around them, causing them to feel hard to adapt to their surroundings as they will choose to believe what they believe. Their changes in body shape as well as sexual functions, also caused them to question these developments and begin to feel attracted to those from different genders. They now tend to be more curious about their daily lives that will influence their cognitive ability to think. Unfortunately, at this level, they are still unable to see the consequences of every action they made.

\section{Middle Adolescence (14 to 17 years old)}

At this phase, the teens began to feel the changes in their physical being that are starting to fully develop for adulthood. Most of the time they start to search for their identity, the curiosity in wanting to know members of the different gender, and at times began to imagine sexual thoughts. Not to mention, they now have better knowledge and are more mature at this point in their life. Besides that, at this phase, they will still need close supervision from their parents in order to avoid any aberrations of social behaviour.

\section{Late Adolescence (18 to 20 years old)}

Youth, particularly in this phase, will experience a consolidation process towards adulthood which will be indicated by their interest in intellectuals, the ego that enables them to socialise with others and gain new experience, having a constant sexual identity or orientation, able to balance between personal interests and those of others, as well as having boundaries and able to differentiate the bad from the goods.

Between the ages of 10 and 19 years old, the transition between childhood and adulthood is one of the most extraordinary stages of human development. [23]. This is the phase in which adolescents undergo the rapid growth of physical, cognitive, and psychosocial. In the adolescent years, there is, however, a significant number of injuries, illnesses as well as death, even though youth is considered as the healthy stage of life due to behaviour patterns that could either protect or jeopardise their health or those around them.

With health issues are now becoming a concern with the outbreak of the COVID-19 pandemic, adolescents are now considered to be vaccinated after most Malaysian adults have been fully vaccinated when the vaccine for COVID-19 was not licensed for those below 12 [24]. As a result, it was encouraged that individuals in close proximity to them, such as teachers, caregivers, household members, and others, get vaccinated as well. A set of clinical guidelines for the COVID-19 immunisation of teenagers was released in July 2021 by Malaysia's Ministry of Health and prioritises individuals with underlying medical issues. The recommendations suggested that adolescents between ages 12 and 17 years old should receive two (2) standard doses of the Comirnaty (Pfizer-BioNTech) vaccine and should be given 21 days apart at least.

As of October 26, 2021, about 73\% of the Malaysian adults' population has been fully vaccinated, $4.5 \%$ partially vaccinated, while the remaining $23 \%$ are still unvaccinated [25]. Worried about the increasing number of COVID-19 infecting those under 18 years old, Director General of Health, Tan Sri Noor Hisham Abdullah expressed his concern especially towards the inclining number of youth's death pertaining to this pandemic [26]. Eventually, the Malaysian Health Minister, Khairy Jamaluddin aimed to vaccinate up to $60 \%$ of those between the age of 12 and 17 years old by November 2021. When almost 70 deaths were recorded among children as of September 2021, the statistics were worrying among Malaysians. Conditional approval was given by Drug Control Authority (DCA) for those above 12 years old to be vaccinated.

The effort to ensure adolescents to be protected against COVID-19 infection enabled them to get vaccinated through appointments from the school's PPV (Pusat Pemberian Vaksin / Vaccination Centre) or simply walk-in to any selected PPV [27]. The teenagers will need their parents to fill up and sign the consent form in the presence of a medical officer. The national immunisation programme against COVID-19 will include over 3.2 million teenagers aged 12 to 17 in the country to be vaccinated. While those below 12 will only be protected by those around them - teachers and support staff - to be fully vaccinated at school premises due to unapproved use of any COVID-19 vaccine on children under 12 years old by National Pharmaceutical Regulatory Agency (NPRA).

By October 25, 2021, 55\% of Malaysian adolescents (aged 12 to 12 ) have been fully vaccinated while $26 \%$ 
have been partially vaccinated and the remaining $18 \%$ unvaccinated [25]. It was expected that by October 27, 2021 , the number of adolescents being fully vaccinated should be at $60 \%$. Despite the reported case of 5 deaths among teenagers after vaccination, it was clarified by the Malaysian Ministry of Health that the death was not caused by the vaccine itself but due to their chronic diseases (two teens with Type 1 diabetes and congenital heart problem respectively), COVID-19 infection before the immunisation programme, and others with only severe side effects of Comirnaty (Pfizer-BioNTech) vaccine which requires hospitalisation [28]. Due to the viral statement made by some social media users, the Ministry of Health strictly advised the users to be responsible for their actions and consequences that they may have caused to the public which may or may not be fake news.

The main issues of Malaysia's COVID-19 immunisation programme for teens are mainly misinformation as well as anxiety due to the circulation of several viral videos online [29]. The immunisation programme is one of the aims to widen the vaccination effort while transitioning towards the COVID-19 endemic phase. According to Deputy Health Minister Noor Azmi Ghazali, the irresponsible act of disseminating unverified videos has caused fear to spread among public especially the parents' confidence. There should be no human error in accordance with the COVID-19 vaccination programme because no one should tolerate anything regarding the matter of life and death.

\subsection{Social Media in Malaysia}

The recent media forms involving interactive participation of its users are the common definition of social media [30]. Being in the interactive age, the interaction between individuals is now becoming so much easier and wider than before, especially with the advancement of digital and mobile technologies, causing new media age to rise with interactivity as its main and newest media function.

The use of social networking sites (SNS) was dragged back in the 1990s where people interact, which includes the emergence of public policy advocacy and social network-based on the web, blogging services [31]. Social media then changes the individuals and organisations ways of interactions through the sharing of mutual interest in terms of friendship, music, movies, as well as education in the 2000s [32]. Several sites began to launch like Myspace, Friendster, LinkedIn, Facebook, Yahoo!360, YouTube, and many more began to receive interaction from its users.
Social media now are taking many forms, which include photographs, videos, Internet forums, magazines, social blogs, podcasts, social bookmarking, and many more [33]. However so, in an event with a variety of social media forms, the primary function to use it is for the purpose of extensive communication. Youngsters are now hooked on different platforms of social media just to stay in touch with their peers. Social media users in Malaysia consist of $86 \%$ of the country's population which is about 28 million users as of January 2021 [34]. In 2020, it was recorded that the most popular platforms of social media among Malaysian users were Facebook, Instagram, Facebook Messenger, as well as LinkedIn. Ever since Facebook was launched in 2004, it has been the most extensively used social media platform among users of social media in Malaysia. Now, it is estimated that Facebook users will be at approximately 24 million by the year 2023 considering the constant growth in the platform.

It depends on the user's motivations for using social media sites to determine whether or not they are advantageous. As a result of the rapid improvements in technology, social media has also caught the interest of people of all ages [35]. Teenagers in particular view social media as a recent trend to fill their free time with activities as well as socialising in cyberspace. Social media can be used as a medium to find and reconned with separated old friends, a platform for sharing knowledge and information, a space for entrepreneurs to market their products and services offered online, a tool to deliver news quickly and accurately, as well as alleviating the users' daily tasks like purchasing goods and banking transactions that can now be managed online.

Social media in a way has somewhat improved the effectiveness and added even more channels of communication as it is much easier now to send messages and get responses instantly [32]. Not only that, but it can also help reach a wider audience with conversations with different forums. Evidently, in education, it could in a way improve students' academic performance with better communication and collaboration, the ability to find concrete information online, involvement of parents, improving students' literacy, reading and communication skills, as well as distance learning opportunities [36]. Each benefit of social media in education will be defined as follows:

\section{Better communication and collaboration}

Students are now able to connect at any time with anyone using the social media platforms using a variety of technological tools like smartphones, computers, tablets, and they are now able to make phone calls, video calls while 
exchanging questions. It will make the students easier to engage with their peers or fellow educators without having to wait and meet them physically. Social media now promotes learning by sharing documents support via Google Drive, Google Docs, Google Sheets, and many more.

\section{Ability to find Concrete information online}

A lot of social media networks and websites are not providing helpful information for students using news feeds on social media, which will enable the students to look for relevant and information based on any websites they choose to follow to keep updated. Based on their interests, students can now look for answers to their questions while getting inspired by their projects or problem-solving tasks through sites like Tumblr or Pinterest.

\section{Involvement of parents}

Parents can now be more involved in their children's learning activities by staying updated through the school's social media accounts - like Facebook or Twitter - mainly on projects and occurring events. The student's progress can now be easily shared with the parents through any secured online platforms used by the educational institution, which can allow the parents to monitor the children's academic performance while providing academic support at home.

\section{Improving students' literacy, reading, and communication skills}

Students are easily bored when it comes to writing and reading activity while with Internet and social media, it can now provide a range of information that students are more inclined to read especially one that includes catchy animations. Students are now more motivated to spend their time and efforts in their learning when it comes to anything that includes an endless list of information like comments, news, online messages, books, and articles. Online activities now can allow students to adopt better reading habits that will improve their writing skills.

\section{Opportunities in distance learning}

There is now a significant advantage for the education industry due to the widespread use of social media, which has allowed many students to participate in distance learning programmes, particularly for those who are poor and are unable to attend classes in person. To help students in rural locations acquire access to education, it was projected that distance learning would be integrated into the modern educational system.

The use of social media has even been extended towards other functionality like campaigns. While trying to ensure a campaign to be successful, it needed to be planned and strategized in advance [37]. To get what we strive for in our goals for the social media campaigns, one will need a marketing strategy with a data-driven base to help construct the direction of the campaign. Corporates will usually use integrated social media marketing strategies to boost sales, leads and increase engagement.

Due to the ability of social media to reach mass audiences about our business, it can now improve the awareness of a brand, increase the website's visitors number, and most importantly earn even more money [38]. The use of social media lets businesses connect with consumers to increase visibility and create loyalty. Several reasons for a more effective marketing campaign are by using it strategically by posting on the right channels of social media, maximising costeffectiveness, improving visibility on a search engine, and tracking the impact of the social media campaign.

One compelling advantage of using social media tools for campaigns is that the promotional content could be adjusted and tailored to fit a specific group of people in the population making it even easier to fill the programs' reachability gaps [39]. Studies have shown that using social media for recruitment was more effective than traditional methods as it is lower in cost, faster, and wider representatives of the general population for people with demographic characteristics which was proven to be one of the most effective strategies.

While planning the social media campaign is somewhat important, it is also crucial for one to develop how the success is going to be measured to track the success of the campaign which is by considering the end goal of the campaign to assure that the campaign will push the results we anticipated [40]. The most common metrics for sites like Facebook, Twitter, and Instagram for tracking social media campaigns through impressions, reach, page likes, site traffics, and engagements. With the right benchmarks accordingly to one's own size for followings, rate of engagement, average impressions/reach, comments, and share, it will be easier to fully grasp the overall effectiveness of the campaign.

Social media's ability is not only reach audiences, but also be impactful, low-cost, and effective is the reason why businesses are now taking social media campaigns as one of the most important marketing 
techniques [41]. Considering the billions of users on a variety of social media platforms, it is difficult for anyone or any business to stay relevant without being present on social media especially with the growth in its monthly users and influence. In general, we could really say that a social media campaign is a marketing effort coordinated with the aim of assisting and reinforce a business goal through one or more social media platforms [42]. That being said, there will be a difference between everyday use and business that put efforts in social media usage as they are more targeting, which is intended to increase focus and measurability.

\subsection{Vaccine Hesitation}

Vaccine hesitancy is a public health issue defined as a delay in accepting or refusing vaccination in the face of available vaccination services [43]. The WHO defines vaccine hesitancy as "the reluctance or refusal to vaccinate despite the availability of vaccines" [44]. Vaccine hesitancy is a difficult problem that varies depending on time, place, and vaccine, and it is also difficult to solve because of its numerous causes, difficulty describing them, and lack of a clear solution [45]. This small group is heterogeneous, with some who are completely opposed to all vaccines, others who are opposed to some vaccines, and still others who are hesitant. Vaccine skeptics are concerned about the safety, necessity, and efficacy of vaccines [46]. Vaccine aversion jeopardises herd immunity by resulting in under-immunization [47]. Under immunization increases the risk of vaccine-preventable disease outbreaks [48]. Vaccine hesitancy was named one of the top ten global health threats by the WHO in 2019, stating that it jeopardises progress in addressing vaccine-preventable diseases [49].

However, this is not a new movement. In 1853, a small segment of the population rejected mandatory vaccination of infants because the parents' decision was not considered [50]. A variety of factors caused vaccine hesitancy. Lin et al. [51] reported that from March 2020 $(>70 \%)$ to October 2020 (50\%), there was a decrease in general COVID-19 vaccine receptivity (regardless of vaccine manufacturer). Brazil, South Africa, Denmark, and the United Kingdom were the most accepting of COVID-19 vaccines at the time, with $80 \%$ acceptance. Countries such as Russia and France, on the other hand, demonstrated a significantly high level of uncertainty regarding COVID-19 vaccines, with vaccine acceptance rates of around 55\%. Malaysia has a similar acceptance rate to Saudi Arabia (64.7 percent) [52] and the United Kingdom (64 percent) [53], but it is lower than China (91.3 percent) [54] and Indonesia (93.3 percent) [53]. Although the acceptance rate is similar to that of Saudi Arabia, one significant difference is that in Malaysia, younger age groups were more accepting than older age groups, whereas, in Saudi, older age groups were more accepting.

Vaccine acceptance studies have revealed that those with higher income and education levels are more likely to accept a vaccine $[55,56]$. It also associated higher trust in government decisions with greater willingness to be vaccinated [57]. Responding to people's needs, as demonstrated by the provision of high-quality goods and services, is an important indicator of government competence. The development of several effective COVID 19 vaccines in less than a year is an impressive demonstration of public authorities' ability to stimulate scientific R\&D efforts for the greater good, as well as an example of the advantages of international collaboration between public and private stakeholders.

Ironically, recent reports of rare but serious adverse events with a probable causal link to the Oxford/AstraZeneca vaccine have put trust in vaccine safety to the test. Both the safety signal and the various responses of regulators around the world are likely to have eroded public trust. However, there is evidence to suggest that as more people are vaccinated, they will be more willing to accept vaccination. While this may reflect a gradual dissipation of initial concerns about the safety of novel vaccines (recent events notwithstanding), it may also reflect that getting vaccinated gradually becomes normative and is increasingly accepted as a means of escaping restriction and confinement [58].

\section{METHODOLOGY}

This study applied a qualitative method of focus group discussion in order to collect the data from the targeted informants which were Malaysian Youths. The main rationale for employing focus group discussion in this study was to obtain in-depth information from the informants about their perceptions towards the Let's Get Vaccinated Campaign conducted by the Malaysian Government on social media. This study conducted five (5) focus group discussions and involved eight (8) participants per session. According to [59], saturation may be reached at three to six focus groups. Besides, [60] suggest that six to eight participants are sufficient.

The informants in this study were selected based on purposive sampling. Purposive sampling refers to the sample that involves participants who have specific characteristics of features [61]. The selection of the Malaysian Youths in this study was based on the following characteristics: (1) aged between 15-30 years; (2) have seen Let's Get Vaccinated Campaign conducted by the Malaysian Government on social media; and (3) 
actively using social media. The findings were analysed using a thematic analysis method. Thematic analysis is a method used for identifying, analysing, and reporting patterns that refer to the 'themes' within data. It also minimally organizes and describes data set in (rich) details [62]. In order to analyse data using thematic analysis, this study followed six processes in the thematic analysis as suggested by [62] i.e. (1) familiarising data; (2) generating initial codes; (3) searching for themes; (4) reviewing themes; (5) defining and naming themes and (6) producing the report.

\section{RESULTS AND DISCUSSION}

The result is based on three fundamental questions that were asked to the informants during the focus group discussion. The questions were: (1) What are the views of Malaysian Youths on the Let's Get Vaccinated Campaign conducted by the Malaysian Government on social media? (2) To what extent do the vaccination awareness campaigns conducted by the Malaysian Government on social media affect the Malaysian Youths? and (3) What are the perception of Malaysian Youths towards anti-vaccine groups in Malaysia?

\subsection{What are the views of Malaysian Youths on the Let's Get Vaccinated Campaign conducted by the Malaysian Government on social media?}

Malaysian Youths have a good and positive perception of the Let's Get Vaccinated Campaign conducted by the Malaysian Government on social media. This can be seen through their feedback in terms of impact, message, and platform related to that campaign.

\subsubsection{Impact}

In terms of impact, Malaysian Youths stated that the Let's Get Vaccinated Campaign conducted by the Malaysian Government on social media gave a positive impact on them. This is because the campaign reminded them of their responsibility as Malaysians to help stop the spread of coronavirus through vaccination. Malaysian Youths believe that vaccination is one of the best ways to protect everyone who is eligible for COVID-19.

\subsubsection{Message}

In terms of message, Malaysian youths stated that the message conveyed was clear, informative, and easy to understand. This is due to the use of simple and straightforward sentences as well as the use of words that are understood by all groups of society. They also informed that the message conveyed repeatedly on social media regarding the importance of vaccination was very good. The repetition of messages can make the public aware of the importance of vaccination to all parties if they want to be free from COVID-19.

However, in terms of creativity, Malaysian youths stated that the message conveyed was not creative enough. They suggested to the government to use the element of entertainment and drama in order to grab the attention of society, especially the young generation. They also suggested delivering the message through songs, short movies, and animated videos. Besides, they believed it is important to select the best and reliable spokesperson to speak on the importance of vaccination. This is to ensure the public pays attention to the messages and are ultimately influenced by the message conveyed.

\subsubsection{Platform}

Malaysian youths stated that, the use of social media by the government in conducting the Let's Get Vaccinated Campaign is appropriate and suitable. This is because social media is the most widely used platform by Malaysians to get information. In addition, social media has various advantages such as it's free for everyone, messages can be delivered quickly, and can reach a large audience. Malaysian Youths also explained that they often see the campaign related to the importance of vaccination on Twitter and Instagram.

However, Malaysian youths suggested to the government to focus only on the five most active social media platforms in Malaysia to ensure the message can be conveyed effectively. As mentioned by Malaysian Youths, there are five most active social media platforms in Malaysia; (1) TikTok; (2) Twitter; (3) Facebook; (4) Instagram and (5) YouTube. They also believe the use of these five social media platforms will be able to help the government to deliver the messages related to the importance of vaccination effectively and quickly. This is because each of the platforms have its own advantages and strengths.

\subsection{To what extent do the vaccination awareness campaigns conducted by the Malaysian Government on social media affect the Malaysian Youths?}

Based on the result, the Let's Get Vaccinated Campaign conducted by the Malaysian Government does not affect the beliefs and behaviour of Malaysian Youths

\subsubsection{Beliefs}

In general, Malaysian youths believe that vaccination can prevent the transmission of COVID-19. However, their belief in the importance of vaccination was not due to being influenced by awareness 
campaigns conducted by the Malaysian Government. They mentioned that the awareness campaign was carried out relatively late by the government. They also informed that their belief in the importance of vaccination was due to being influenced by the messages and information conveyed by a medical specialist and family members.

\subsubsection{Behaviour}

The Malaysian government's vaccination awareness campaign had little impact on the decisions and actions of Malaysian youngsters, according to their responses. But their decisions and actions of taking the vaccine were due to several factors; (1) self -awareness; (2) influenced by parents and peers; and (3) from the experience of the close friends and family members infected with COVID-19.

\subsection{What are the perceptions of Malaysian Youths towards anti-vaccine groups in Malaysia?}

Malaysian youths have a negative perception of the anti-vaccine group in Malaysia. They argue that the anti-vaccine groups are selfish, stubborn, misguided, annoying, problematic, and troublesome. As stated by Malaysian Youths, anti-vaccine groups in Malaysia are actively using social media to spread fear and myths about COVID-19 to the publics. Facebook is the most widely used social media platform by anti-vaccine groups in spreading false information about vaccines.

Although anti-vaccine groups are actively disseminating false information about vaccines on social media, however, the information spread by the antivaccine group does not influence and affect Malaysian Youths. They can distinguish the accurate information from the false information based on their reading and discussion with their friends, lecturers, and family members.

\section{CONCLUSION}

This study investigates Malaysian Youth's perception towards Let's Get Vaccinated Campaign conducted by the Malaysian Government on social media. Overall, Malaysian youths have a good perception of the Let's Get Vaccinated Campaign conducted by the Malaysian Government on social media. This can be seen through their positive feedback on the messages and platforms used by the government. However, there are improvements that need to be made to ensure the effectiveness of the campaign in the future.
The improvements are related to the creativity in conveying the message as well as the importance of choosing the right spokesperson in spreading the message on the importance of vaccines to the community. According to [63], the more creativity we can use, the more eye-catching and attention we can get from our target audience. Besides, as mentioned by [64], choosing a spokesperson is one of the most important things we will do when implementing a communications strategy. This is because it's related to the reputation of our work through consistency, competency, expertise, inspiration, and warmth. Although Malaysian Youths have a good perception of the Let's Get Vaccinated Campaign conducted by the Malaysian Government on social media, the campaign does not influence and affect their beliefs and behaviours regarding the importance of vaccination. The awareness campaign was carried out relatively late by the government, and Malaysian Youths are depending on the messages and information conveyed by a medical specialist and family members which ultimately influences them to believe and take the vaccine.

\section{ACKNOWLEDGMENTS}

This study has been funded by UiTM Alor Gajah, Melaka. The funding source had no involvement in the design or conduct of the study.

\section{REFERENCES}

[1] F. A. Rosli, "Program vaksinasi berjaya turunkan kes positif serius COVID-19," Berita Harian Online, 2021. https://www.bharian.com.my/berita/nasional/2021/ 07/840472/program-vaksinasi-berjaya-turunkankes-positif-serius-covid-19 (accessed Oct. 28, 2021).

[2] M. Z. Mustafa, "Kempen Kerajaan Dalam Menentang COVID-19 di Malaysia," Universiti Islam Malaysia, pp. 23-25, 2021.

[3] D. Baum, M. Spann, J. Füller, and C. M. Thürridl, "The impact of social media campaigns on the success of new product introductions," J. Retail. Consum. Serv., vol. 50, pp. 289-297, 2018, doi: 10.1016/j.jretconser.2018.07.003.

[4] M. C. and M. Commission, "Internet Users Survey 2020," MCMC, 2020. https://www.mcmc.gov.my/skmmgovmy/media/Ge neral/pdf/IUS-2020-Report.pdf (accessed Oct. 29, 2021).

[5] A. Selepak, "Social Good from Social Media," College of Journalism and Communication, University of $\quad 2017$. 
https://www.jou.ufl.edu/insights/social-good-fromsocial-media/ (accessed Oct. 29, 2021).

[6] A. R. A. Mohd Mahzan Awang and K. A. Ghani, "Ekstremisme dalam Kalangan Belia Berpendidikan Tinggi di Malaysia: Pengkonsepsian dan Faktor yang Mendorong," J. Malaysian Stud., pp. 1-26, 2021.

[7] M. H. Mahmud and K. H. Siarap, "Kempen Pencegahan H1N1: Kajian Tentang Pengetahuan, Sikap Dan Amalan Penduduk Di Timur Laut Pulau Pinang," Malaysian J. Commun., vol. 29, no. 1, pp. 127-140, 2013.

[8] N. Jaafar, "Situasi PPV PWTC terkawal," Sinar Harian Online, 2021. https://www.sinarharian.com.my/article/141345/K HAS/Covid-19/Situasi-PPV-PWTC-terkawal (accessed Oct. 29, 2021).

[9] Z. Mohamad, "Jom Vaksin hapus prasangka terhadap imunisasi," Berita Harian Online, 2021. https://www.bharian.com.my/hiburan/selebriti/202 1/06/830665/jom-vaksin-hapus-prasangkaterhadap-imunisasi (accessed Oct. 29, 2021).

[10] L. M. McLernon, "One COVID vaccine dose yields good protection in elderly, 2 studies find," Center for infectious Disease Reserach and Policy, 2021. https://www.cidrap.umn.edu/newsperspective/2021/06/one-covid-vaccine-doseyields-good-protection-elderly-2-studies-find (accessed Oct. 29, 2021).

[11] M. H. Jamri, N. Z. Ismail, A. Jamilah, and D. Singh, "Kempen Kesedaran Kesihatan Awam: Satu Tinjauan Literatur dari Sudut Penggunaan Media dan Komunikasi di Malaysia," Malaysian J. Commun., vol. 33, no. 3, pp. 1-20, 2017.

[12] D. Diana and M. Nizam, "Pengaruh Faktor Sosial Kesan Kempen Media Tak Nak Merokok Kementerian Kesihatan Malaysia," Malaysian J. Commun., vol. 29, no. 1, pp. 179-198, 2013.

[13] E. Mohamad, N. A. M. Haniff, S. M. Salleh, A. L. Ahmad, and H. Hashim, "Media dan literasi kesihatan: pemilihan susu tumbesaran kanakKanak dalam kalangan ibu," Malaysian J. Commun., vol. 31, no. 2, pp. 83-97, 2015.

[14] S. N. Sannusi and K. Siarap, "Peranan perhubungan awam dan komunikasi krisis: kajian terhadap Kementerian Kesihatan Malaysia dalam penanganan wabak SARS," J. Soc. Sci. Humanit., vol. 9, no. 2, pp. 125-134, 2014.

[15] D. F. Baharudin, Z. A. Ahmad, A. H. M. Hussin, and Z. Zakaria, "Preliminary Findings on the Use of Anti-Drug Campaigns and Communication
Strategies to Increase Awareness about the Dangers of Drug Abuse in Malaysia,” 2012.

[16] United Nations, 2021. Youth| United Nations. [Online] United Nations. Available at: https://www.un.org/en/global-issues/youth [Accessed: 25 October 2021].

[17] Yunus, A. and Landau, E., 2021. 'Youth' now defined as those between 15 and $30 \mid$ New Straits Times. [Online] NST Online. Available at: https://www.nst.com.my/news/nation/2019/07/50 1288/youth-now-defined-those-between-15-and30 [Accessed: 25 October 2021].

[18] Harlan, M., 2016. Constructing Youth: Reflecting on Defining Youth and Impact on Methods. School Libraries Worldwide, [Online] 22(2), pp.1-12. Available at: https://iaslonline.org/resources/Documents/Harlan1-12.pdf [Accessed: 25 October 2021].

[19] Braun, Y., Plottka, J. and Smirnova, E., 2021. Young Central Asia: Recommendations to the German Government for the Implementation of the EU-Central Asia Strategy. Institut für Europäische Politik, [Online] 01(21), pp.2-36. Available at: http://iep-berlin.de/wpcontent/uploads/2021/03/Young-Central-AsiaRecommendations-to-the-German-Governmentfor-the-Implementation-of-the-EU-Central-AsiaStrategy.pdf [Accessed: 25 October 2021].

[20] Mayasari, A., Febriyanti, H. and Primadevi, I., 2021. Kesehatan Reproduksi Wanita di Sepanjang Daur Kehidupan. 1st ed. Aceh: Syiah Kuala University Press, pp.25-27.1

[21] Kusmiran, E., 2011. Kesehatan Reproduksi Remaja dan Wanita. Bandung: Salemba Medika.

[22] Wirenviona, R., 2020. Edukasi Kesehatan Reproduksi Remaja. Surabaya: Airlangga University Press, pp.2-3.

[23] World Health Organization, 2021. Adolescent health. [Online] WHO. Available at: https://www.who.int/health-topics/adolescenthealth\#tab=tab_1 [Accessed: 25 October 2021].

[24] Ministry of Health, Malaysia, 2021. Clinical Guidelines on COVID-19 Vaccination for Adolescents (12-17 Years) in Malaysia. 1st ed. Ministry of Health, pp.2-6.

[25] Ministry of Health, Malaysia, 2021. Vaccinations in Malaysia. [Online] COVIDNOW. Available at: https://covidnow.moh.gov.my/vaccinations/ [Accessed: 25 October 2021]. 
[26] The Straits Times, 2021. 80\% of eligible kids in Malaysia to be fully vaccinated before school reopens in 2022. [Online] The Straits Times. Available at:

https://www.straitstimes.com/asia/se-asia/67children-in-malaysia-died-due-to-covid-19-thisyear-80-of-all-eligible-kids-to-be [Accessed: 25 October 2021].

[27] Kaos Jr., J.,2021. Options for teens to get Jabs. [Online] The Star. Available at: https://www.thestar.com.my/news/nation/2021/0 9/21/options-for-teens-to-get-jabs. [Accessed at: 25 October 2021].

[28] Huda, N., 2021. COVID-19: Dakwaan lima remaja maut selepas divaksin, ini jawapan KKM. [Online] Astro Awani - Berita Malaysia. Available at: https://www.astroawani.com/beritamalaysia/covid19-dakwaan-lima-remaja-mautselepas-divaksin-ini-jawapan-kkm-322527. [Accessed: 25 October 2021].

[29] Anand, R., 2021. Misinformation, anxiety plague Malaysia's covid-19 vaccination programme for teens. [Online] The Straits Times - ASIA.

[Online]. Available at: https://www.straitstimes.com/asia/seasia/misinformation-anxiety-plague-malaysiasteenage-covid-19-vaccination-programme. [Accessed: 25 October 2021].

[30] Manning, J., 2014. Social media, Definition and classes of in Encyclopedia of Social Media and Politics, California: SAGE Publications, pp. 1158-1162.

[31] Riholtz, B, 2010. History of Social Media. [Online] The Big Picture. Available at: https://ritholtz.com/2010/12/history-of-socialmedia/ [Accessed: 25 October 2021].

[32] Junco, R., Heibergert, G., \& Loken, E., 2011. The effect of Twitter on college student engagement and grades in Journal of Computer Assisted Learning, 27, pp. 119-132.

[33] Baruah, T. D., 2012. Effectiveness of Social Media as a tool of communication and its potential for technology enabled connections: A micro-level study in International Journal of Scientific and Research Publications, 2(5), pp. 110 .

[34] Müller, J., 2021. Social media users as a percentage of the total population Malaysia 2021. [Online] Statistica. Available at: https://www.statista.com/statistics/883712/malay sia-social-media-penetration/ [Accessed: 25 October 2021]

[35] Fauzi, N., 2017. Penggunaan Media Sosial dalam Duna Tanpa Sempadan: Suatu Kebaikan atau Keburukan? [Online] Intstitut Latihan Kehakiman dan Perundangan (ILKAP). Available at: https://www.ilkap.gov.my/download/kertaspenye lidikan/PMSDDTS18122017.pdf [Accessed: 25 October 2021]

[36] Willbold, M., 2019. Social Media In Education: Can They Improve The Learning? [Online] eLearning Industry. Available at: https://elearningindustry.com/social-media-ineducation-improve-learning [Accessed at: 25 October 2021]

[37] Bullock, L., 2021. How to plan a social media marketing campaign, step by step. [Online] Available

https://www.smartinsights.com/social-mediamarketing/social-media-strategy/how-to-plan-asocial-media-marketing-campaign-step-by-step/ [Accessed: 26 October 2021]

[38] Aguirre, V., 2020. The Importance of Strategic Social Media Campaigns. [Online] Available at: https://becomedistinct.com/blog/importancestrategic-social-media-campaigns/ [Accessed: 26 October 2021]

[39] Rayward, A. T., Vandelanotte, C., Corry, K., Itallie, A. V., \& Duncan, M. J., 2019. Impact of a Social Media Campaign on Reach, Uptake and Engagement with a Free Web- and App-Based Physical Activity Intervention: The 10,000 Steps Australia Program in International Journal of Environmental Research and Public Health, 16, pp. 1-17.

[40] Friedman, Z., 2018. How to measure the Effectiveness of a Social Media Campaign. [Online] Power Digital. Available at: https://powerdigitalmarketing.com/blog/measureeffectiveness-social-media-campaign/\#gref [Accessed: 26 October 2021]

[41] Baker, K., 2019. The Ultimate Guide to Social Media Marketing Campaigns. [Online] HubSpot. Available at: https://blog.hubspot.com/marketing/socialmedia-campaigns [Accessed at: 26 October 2021]

[42] Big Commerce Pty. Ltd., 2021. What is a social media campaign? How to increase sales. [Online] Available at: 
https://www.bigcommerce.com/ecommerceanswers/what-is-a-social-media-campaign/ [Accessed: 26 October 2021]

[43] MacDonald NE, SAGE Working Group on Vaccine Hesitancy. Vaccine hesitancy: Definition, scope and determinants. Vaccine 2015; 33(34): 4161-4.

[44] WHO Strategic Advisory Group of Experts on Immunization. Report of the SAGE Working Group on Vaccine Hesitancy. WHO Strategic Advisory Group of Experts on Immunization (2014).

[45] Shen AK. Finding a way to address a wicked problem: vaccines, vaccination, and a shared understanding. Hum Vaccines Immunother. (2020) 16:1030-3. doi: 10.1080/21645515.2019.1695458

[46] Larson HJ, Jarrett C, Eckersberger E, Smith DM, Paterson P. Understanding vaccine hesitancy around vaccines and vaccination from a global perspective: a systematic review of published literature, 2007- 2012. Vaccine 2014; 32(19): 2150-9

[47] Deml MJ, Jafflin K, Merten S, Huber B, Buhl A, Frau E, et al. Determinants of vaccine hesitancy in Switzerland: study protocol of a mixed-methods national research programme. BMJ Open 2019; 9(11): e032218

[48] Diekema DS. Personal belief exemptions from school vaccination requirements. Annu Rev Public Health 2014; 35: 275-92

[49] Dubé È, Ward JK, Verger P, Macdonald NE. Vaccine hesitancy, acceptance, and antivaccination: trends and future prospects for public health. Annu Rev Public Health. (2020) 42:175-91. doi: 10.1146/annurev-publhealth-090419-102240

[50] Weber, T.P. Alfred Russel Wallace and the Antivaccination Movement in Victorian England. Emerg. Infect. Dis. 2010, 16, 664-668

[51] Lin C, Tu P, Beitsch LM. Confidence and receptivity for COVID-19 vaccines: a rapid systematic review. Vaccines. (2021) 9:16. doi: 10.3390/vaccines9010016

[52] Al-Mohaithef M, Padhi BK. Determinants of COVID-19 Vaccine Acceptance in Saudi Arabia: A Web-Based National Survey. J Multidiscip Healthc. 2020;13:1657. pmid:33262600

[53] Harapan H, Wagner AL, Yufika A, Winardi W, Anwar S, Gan AK, et al. Acceptance of a COVID19 vaccine in southeast Asia: A cross-sectional study in Indonesia. Front public Heal. 2020;8.
[54] Wang J, Jing R, Lai X, Zhang H, Lyu Y, Knoll $\mathrm{MD}$, et al. Acceptance of covid-19 vaccination during the covid-19 pandemic in china. Vaccines. 2020;8(3):1-14. pmid:32867224

[55] Fisher, K.A.; Bloomstone, S.J.; Walder, J.; Crawford, S.; Fouayzi, H.; Mazor, K.M. Attitudes Toward a Potential SARS-CoV-2 Vaccine: A Survey of U.S. Adults. Ann. Intern. Med. 2020, 173, 964-973.

[56] Reiter, P.L.; Pennell, M.L.; Katz, M.L. Acceptability of a COVID-19 vaccine among adults in the United States: How many people would get vaccinated? Vaccine 2020, 38, 65006507

[57] Lazarus, J.V.; Ratzan, S.C.; Palayew, A.; Gostin, L.O.; Larson, H.J.; Rabin, K.; Kimball, S.; ElMohandes, A. A global survey of potential acceptance of a COVID-19 vaccine. Nat. Med. 2020.

[58] Bish, Alison, et al. "Factors associated with uptake of vaccination against pandemic influenza: a systematic review." Vaccine 29.38 (2011): 64726484 .

[59] Guest, G., Namey, E. and McKenna, K. (2016). How Many Focus Groups Are Enough? Building an Evidence Base for Nonprobability Sample Sizes. Field Methods, 29(1), 3-22. doi.org/10.1177/1525822X16639015.

[60] Krueger, R., Casey, M. (2015). Focus Groups: A Practical Guide for Applied Research. 5th ed. Thousand Oaks, CA: Sage.

[61] Coyne, I. T. (1997). Sampling in qualitative research. Purposeful and theoretical sampling; merging or clear boundaries?. Journal of Advanced Nursing, 26(3), 623-630.

[62] Braun, V., \& Clarke, V. (2006). Using thematic analysis in psychology. Qualitative Research in Psychology, 3(2), 77-101.

[63]Bower, H. (2017). What Is Creative Communication and How Can It Improve Your Marketing? Retrieved from https://medium.com/keeprising/what-is-creative-communication-and-howcan-it-improve-your-marketing-a2c05578c60d

[64] Tamarindo Group. (2021). How to Find the Right Spokesperson for Your Company. Retrieved from https://www.tamarindocomms.com/blog/how-tofind-the-right-spokesperson-for-your-company 